\title{
Is there a difference in postoperative diuresis and renal function between patients with axial and centrifugal left ventricular assist devices?
}

\author{
Nina Jakuš*, \\ Olvo Planinc, \\ Dora Fabijanović, \\ Boško Skorić, \\ Daniel Lovrić, \\ Hrvoje Jurin, \\ Jure Samardžić, \\ Jana Ljubas Maček, \\ Hrvoje Gašparović, \\ Bojan Biočina, \\ Davor Miličić, \\ Maja Čikeš
}

University of Zagreb School of Medicine, University Hospital Centre Zagreb, Zagreb, Croatia

\begin{abstract}
KEYWORDS: ventricular assist devices, diuresis, renal function
CITATION: Cardiol Croat. 2017;12(9-10):364. | https://doi.org/10.15836/ccar2017.364

*ADDRESS FOR CORRESPONDENCE: Nina Jakuš, Klinički bolnički centar Zagreb, Kišpatićeva 12, HR-10000 Zagreb, Croatia. / Phone: +385-91-5605-795 / E-mail: nina.jakush@gmail.com

ORCID: Nina Jakuš http://orcid.org/0000-0001-7304-1127 • Ivo Planinc http://orcid.org/0000-0003-0561-6704 Dora Fabijanović http://orcid.org/0000-0003-2633-3439 • Boško Skorić http://orcid.org/0000-0001-5979-2346 Daniel Lovrić http://orcid.org/0000-0002-5052-6559 • Hrvoje Jurin http://orcid.org/0000-0002-2599-553X Jure Samardžić http://orcid.org/0000-0002-9346-6402 • Jana Ljubas Maček http://orcid.org/0000-0001-7171-2206 Hrvoje Gašparović http://orcid.org/0000-0002-2492-3702 • Bojan Biočina http://orcid.org/0000-0003-3362-9596 Davor Miličić http://orcid.org/0000-0001-9101-1570 • Maja Čikeš http://orcid.org/0000-0002-4772-5549
\end{abstract}

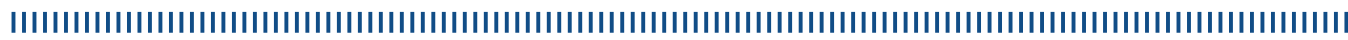

Introduction: Despite being a mainstay of modern advanced heart failure (AHF) therapy, more knowledge is to be gained on the effect of left ventricular assist device (LVAD) treatment on end organs, especially the possible differences between pulsatile and continuous blood flow. ${ }^{1,2}$ We have observed a clinically significant increase in diuresis in our HeartMate3 patient (pt) population, despite minimization/withdrawal of diuretic therapy, and have aimed to examine potential differences in postimplantation renal function (RF) and diuresis between patients treated with Heart MateII (HMII, axial) and Heart Mate3 (HM3, centrifugal) devices.

Patients and Methods: 35 pts were implanted with a HeartMate LVAD during a 4-year period at our centre (2 pts who have expired in the first postoperative month and 8 with lacking data were excluded from further analysis) - 15 pts received HMII (15 men, mean age 62.73 \pm 4.15 ) and 10 pts received HM3 (8 men, mean age 55.8 \pm 10.69 , $p$ value for age $=0.03$ ). Most of the pts received the device for the treatment of AHF due to ischemic cardiomyopathy (60\%), dilated cardiomyopathy (36\%) and LVNC (4\%) (etiology was similarly distributed between the groups). During the 2nd, 3rd and 4th postimplantation week, daily diuresis was measured, as well as fluid intake, diuretic therapy and estimated glomerular filtration rate (eGFR).

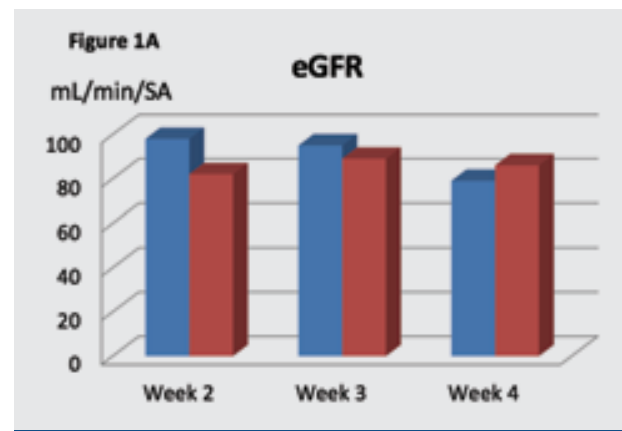

FIGURE 1A. Renal function expressed as estimated glomerular filtration rate (eGFR) was similar between the two groups during the follow up period.

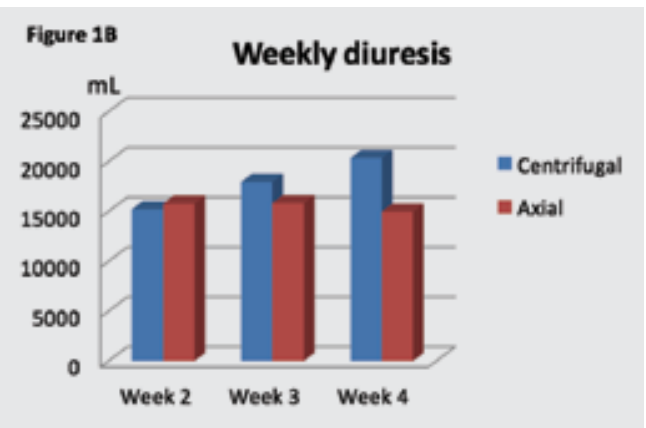

FIGURE 1B. Absolute values of diuresis differed between the two groups, especially in week 4 , although not statistically significant.
Results: RF was preserved, even in the early postoperative period (1st postoperative month), in both pt populations (Figure 1A). Only one pt required intermittent hemodialysis during this period. There was no significant difference in fluid intake or diuretic therapy between the two groups. Despite having similar values of eGFR (centrifugal: 90.67 $\pm 10.21 \mathrm{~mL} / \mathrm{min} / \mathrm{SA}$, axial: $85.67 \pm 3.51 \mathrm{~mL} / \mathrm{min} / \mathrm{SA}$, ns), we observed that the pt population receiving HM3 had greater absolute values of diuresis in the 3rd and 4th week compared to those receiving HMI, although not reaching statistical significance (Figure 1B)

Conclusion: We have objectified an increase in postimplantation diuresis in our cohort of pts treated with continuous vs. axial HM LVADs, however without reaching statistically significant difference in these measurements, while having equally preserved RF. A study in a larger pt population is warranted to obtain better insight to this observation in the early postimplantation period.

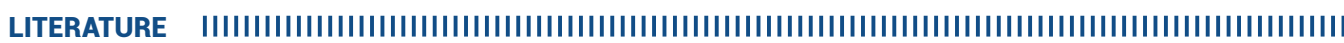
Nadziakiewicz P, Szyqula-Jurkiewicz B, Niklewski T, Pacholewicz J, Zakliczynski M, Borkowski J, et al. Effects of Left Ventricular Assist Device Support on End-Organ Function in Patients With Heart Failure: Comparison of Pulsatile- and Continuous-Flow Support in a Single-Center Experience. Transplant Proc. 2016 Jun;48(5):1775-80. https://doi.org/10.1016/j.transproceed.2016.01.071

2. Yoshioka D, Takayama H, Colombo PC, Yuzefpolskaya M, Garan AR, Topkara VK, et al. Changes in End-Organ Function in Patients With Prolonged Continuous-Flow Left Ventricular Assist Device Support. Ann Thorac Surg. 2017 Mar;103(3):717-724.

https://doi.org/10.1016/j.athoracsur.2016.12.018 